\title{
А.Н. Багашев
}

\section{МЕЖГРУППОВАЯ ИЗМЕНЧИВОСТЬ КРАНИОЛОГИЧЕСКИХ ОСОБЕННОСТЕЙ СЕВЕРНЫХ САМОДИЙЦЕВ И КЕТОВ}

\begin{abstract}
В современной систематике надпопуляционных общностей Северной Евразии отнесение некоторых народов к той или иной таксономической категории является предметом дискуссий. Это касается, в частности, северосамодийских народов (ненцев, энцев и нганасан) и кетов и обусловлено недостатком имеющихся антропологических материалов. Появление новых данных об особенностях физического облика тазовских и лесных ненцев с севера Западной Сибири дало возможность рассмотреть характер их межгрупповой изменчивости. Выявленные закономерности позволяют рассматривать северных самодийцев и кетов в качестве самостоятельного третьего антропологического типа - ямало-енисейского - в составе западносибирской антропологической формации наряду с обь-иртышским и уральским.

Ключевые слова: антропология; популяция; систематика; таксономия; Северная Евразия; северные самодийцы; кеты.
\end{abstract}

Современное аборигенное население Северной Евразии относится к различным этнолингвистическим образованиям (самодийцы, финно-угры, тюрки, кеты, палеоазиаты), в традиционной культуре представлены разнообразные хозяйственно-культурные типы присваивающего и производящего хозяйств. Как велико разнообразие их культур и природно-климатических условий обитания, так велики и антропологические различия между ними, что в целом говорит о различных путях их этногенеза. Антропология освещает лишь одну из сторон происхождения племен - историю формирования особенностей их физического облика, в реконструкции которой важное место занимает таксономическая классификация антропологических общностей, так как она отражает элементы общности и различий в генезисе и исторических судьбах популяций.

Систематике антропологических общностей Северной Евразии уделяется большое внимание начиная с конца XIX в. Наибольшую известность получила систематика И. Деникера [1], которая позднее дополнялась и конкретизировалась Г.Ф. Дебецем, А.И. Ярхо, В.В. Бунаком, Н.Н. Чебоксаровым, В.П. Алексеевым и др. Ими отмечена тенденция ослабления степени выраженности европеоидных особенностей с запада на восток, а Евразийская промежуточная зона обозначена как территория формирования смешанных европеоидно-монголоидных форм в результате длительного контакта и взаимодействия народов запада и востока. Поэтому в качестве основного механизма их генезиса постулируется метисация. Применительно к южносибирским популяциям это доказано, смешение между монголоидными и европеоидными группами на территории Южной Сибири и Казахстана фиксируется с эпохи неолита [2-4]. А вот механизм формирования северных популяций Евразийской промежуточной зоны (выделенных И. Деникером в угорскую, а позднее В.В. Бунаком в уральскую антропологическую общность) трактуется неоднозначно. Одни исследователи в качестве основного фактора их формирования рассматривают смешение $[5,6]$, другие придерживаются мнения о консервации в их генофонде древних недиффе- ренцированных элементов [7, 8]. Объединение популяций в один таксон - уральскую расу, вывело уровень её изменчивости на сходный с другими, что соответствовало принципам классификации К. Линнея.

Однако накопление новых данных об антропологии популяций уральской общности (по тюркам и финнам Приуралья, обским уграм, западносибирским и южносибирским тюркам, северным и южным самодийцам) существенно увеличило уровень ее межгрупповой изменчивости, вариабельность приобрела значительный уровень трансгрессии. Для исправления ситуации было предложено в составе этой совокупности популяций выделить варианты - субуральский, лапоноидный, сублапоноидный, западносибирский, собственно уральский, североалтайский. Однако анализ массива данных показал, что общая изменчивость не уменьшилась, а возросла. В этой связи автором было предложено отказаться от понятия уральской расы как совокупности субуральских (приуральских), североалтайских, западносибирских популяций и кетов [9]. Было обосновано субуральские группы рассматривать в качестве восточного типа североевропейской (беломоро-балтийской) совокупности европеоидных популяций, североалтайские - в качестве особого антропологического типа южносибирской формации, наряду с алтае-саянским и казахстанским. Западносибирские народы (угры, тюрки и южные самодийцы, кроме северных) выделены в локальную западносибирскую общность. Северных самодийцев и кетов было предложено условно отнести к западному варианту североазитских монголоидов енисейскому типу [Там же]. Изменчивость новых таксонов снизилась до сопоставимого, однако в связи с недостатком данных направление расогенетических связей и таксономическое положение северных самодийцев и кетов оставались неопределенными.

Появление новых краниологических материалов по сибирским ненцам, в частности из Надымской и Тазовской тундры $[10,11]$, позволило обратиться к рассмотрению вопроса о характере межгрупповой изменчивости ненцев и кетов и их месту в системе надпопуляционных общностей Северной Евразии. 
Сравнительные краниологические материалы по североевразийским популяциям

Западносибирская антропологическая формация

\begin{tabular}{|c|c|c|c|c|c|c|c|c|c|c|c|c|c|c|c|c|c|c|c|c|}
\hline \multirow{4}{*}{$\begin{array}{c}\text { № по Мартину, } \\
\text { или Условное } \\
\text { обозначение }\end{array}$} & \multicolumn{20}{|c|}{ Западносибирская антропологическая формация } \\
\hline & \multicolumn{6}{|c|}{ Уральский антропологический тип } & \multicolumn{6}{|c|}{ Обь-иртышский антропологический тип } & \multicolumn{8}{|c|}{ Ямало-енисейский антропологический тип } \\
\hline & \multicolumn{2}{|c|}{$\begin{array}{c}\text { Манси } \\
\text { северные }\end{array}$} & \multicolumn{2}{|c|}{$\begin{array}{c}\text { Ханты } \\
\text { северные }\end{array}$} & \multicolumn{2}{|c|}{$\begin{array}{c}\text { Ханты } \\
\text { восточные }\end{array}$} & \multicolumn{2}{|c|}{$\begin{array}{c}\text { Тоболо- } \\
\text { барабинские } \\
\text { тюрки } \\
\end{array}$} & \multicolumn{2}{|c|}{$\begin{array}{l}\text { Томско-чулымские } \\
\text { тюрки }\end{array}$} & \multicolumn{2}{|c|}{$\begin{array}{l}\text { Нарымские } \\
\text { селькупы }\end{array}$} & \multicolumn{2}{|c|}{$\begin{array}{c}\text { Ненцы } \\
\text { тундровые }\end{array}$} & \multicolumn{2}{|c|}{$\begin{array}{c}\text { Ненцы } \\
\text { тазовские }\end{array}$} & \multicolumn{2}{|c|}{$\begin{array}{l}\text { Северные } \\
\text { самодийцы }\end{array}$} & \multicolumn{2}{|c|}{ Кеты } \\
\hline & 0 & q & 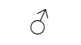 & q & $0^{\lambda}$ & 우 & 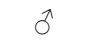 & q & $\widehat{0}$ & 우 & $0^{\lambda}$ & q & $\hat{0}$ & 우 & $\sigma^{\lambda}$ & q & 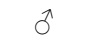 & 우 & 0 & q \\
\hline 1. & 183,9 & 174,4 & 181,9 & 174,4 & 182,3 & 178,8 & 181,6 & 173,0 & 178,4 & 170,2 & 178,0 & 170,2 & 179,2 & 171,0 & 183,3 & 171,3 & 178,4 & 172,9 & 179,6 & 173,0 \\
\hline 8. & 139,5 & 134,2 & 140,3 & 135,4 & 140,2 & 136,7 & 143,4 & 136,9 & 143,4 & 138,0 & 144,2 & 137,4 & 146,6 & 140,7 & 148,0 & 140,9 & 146,4 & 141,2 & 144,8 & 143,0 \\
\hline 17 & 126,1 & 120,6 & 126,6 & 123,3 & 130,9 & 125,2 & 131,7 & 125,9 & 131,4 & 126,2 & 133,1 & 127,1 & 129,0 & 121,3 & 131,6 & 125,5 & 128,9 & 123,3 & 128,7 & 127,3 \\
\hline $8: 1$. & 76,6 & 77,2 & 77,2 & 77,8 & 76,6 & 76,6 & 79,0 & 79,2 & 79,0 & 81,2 & 80,8 & 80,7 & 81,9 & 82,4 & 80,1 & 82,3 & 82,1 & 81,6 & 80,7 & 82,8 \\
\hline 5. & 100,1 & 94,3 & 100,4 & 96,2 & 101,8 & 96,8 & 101,6 & 96,0 & 99,6 & 95,4 & 101,7 & 97,2 & 98,7 & 96,0 & 102,9 & 96,0 & 98,7 & 94,0 & 100,3 & 96,6 \\
\hline 9. & 92,8 & 92,1 & 95,1 & 90,8 & 95,5 & 93,6 & 94,5 & 91,6 & 94,5 & 91,6 & 96,8 & 93,4 & 94,2 & 88,8 & 93,0 & 91,8 & 93,7 & 90,6 & 94,7 & 93,3 \\
\hline 32. & 79,3 & 83,4 & 79,5 & 81,9 & 81,3 & 83,7 & 80,6 & 83,0 & 81,3 & 83,5 & 80,1 & 82,0 & 81,8 & 82,4 & 76,2 & 80,4 & 80,7 & 84,6 & 80,7 & 84,7 \\
\hline 40. & 98,9 & 93,7 & 100,7 & 95,1 & 102,0 & 98,3 & 99,5 & 94,2 & 98,8 & 93,9 & 99,9 & 95,8 & 101,1 & 96,9 & 101,7 & 96,8 & 101,5 & 95,4 & 99,5 & 93,2 \\
\hline 45. & 135,3 & 127,7 & 136,2 & 128,3 & 135,2 & 127,0 & 137,5 & 127,2 & 137,7 & 127,8 & 140,0 & 129,7 & 139,1 & 130,3 & 142,2 & 132,9 & 141,3 & 134,1 & 137,2 & 131,0 \\
\hline 48. & 70,8 & 65,1 & 70,9 & 65,5 & 70,6 & 66,3 & 72,2 & 66,8 & 69,7 & 64,8 & 69,4 & 67,9 & 73,9 & 69,5 & 74,7 & 68,6 & 71,3 & 69,0 & 71,6 & 65,6 \\
\hline 48:45. & 52,3 & 50,1 & 52,0 & 51,1 & 52,4 & 52,3 & 52,6 & 52,7 & 50,8 & 50,8 & 49,7 & 50,3 & 53,1 & 53,3 & 52,6 & 51,9 & 51,2 & 53,0 & 52,2 & 50,1 \\
\hline 72. & 86,5 & 86,3 & 84,4 & 83,6 & 84,2 & 83,1 & 86,0 & 85,6 & 84,8 & 84,4 & 84,4 & 84,3 & 86,1 & 86,6 & 81,7 & 82,0 & 84,5 & 84,7 & 84,8 & 86,1 \\
\hline 77. & 142,1 & 142,8 & 143,4 & 144,7 & 142,2 & 140,7 & 142,7 & 142,8 & 144,0 & 144,2 & 144,6 & 144,4 & 146,4 & 147,4 & 145,9 & 146,3 & 150,3 & 150,4 & 146,3 & 144,6 \\
\hline$\angle \mathrm{zm}$ '. & 135,0 & 135,9 & 135,2 & 134,4 & 133,9 & 133,8 & 133,5 & 133,2 & 134,5 & 134,9 & 135,2 & 134,8 & 135,8 & 135,6 & 132,0 & 131,2 & 136,0 & 136,0 & 133,7 & 135,6 \\
\hline 51. & 41,8 & 40,6 & 43,0 & 41,6 & 42,8 & 41,1 & 43,8 & 42,0 & 43,2 & 41,4 & 43,8 & 42,0 & 42,7 & 40,9 & 43,2 & 40,6 & 42,1 & 42,1 & 42,8 & 41,7 \\
\hline 52. & 34,3 & 33,6 & 34,4 & 34,4 & 34,1 & 32,7 & 33,9 & 33,4 & 33,6 & 33,1 & 33,7 & 33,2 & 34,4 & 33,7 & 35,5 & 34,7 & 34,4 & 34,7 & 34,2 & 34,3 \\
\hline 55. & 52,5 & 48,5 & 52,5 & 49,7 & 51,3 & 48,1 & 52,8 & 49,0 & 51,4 & 47,8 & 51,7 & 48,7 & 53,0 & 51,0 & 54,5 & 51,8 & 52,8 & 50,9 & 52,8 & 48,7 \\
\hline 54. & 26,3 & 24,9 & 25,5 & 25,0 & 26,3 & 25,5 & 26,0 & 25,0 & 26,0 & 24,8 & 26,0 & 25,1 & 25,0 & 25,4 & 25,7 & 25,2 & 25,8 & 24,7 & 25,7 & 24,7 \\
\hline $75(1)$. & 20,2 & 16,4 & 20,8 & 17,7 & 18,9 & 14,8 & 21,0 & 17,5 & 20,1 & 18,0 & 18,2 & 17,1 & 23,3 & 18,2 & 21,8 & 18,6 & 26,7 & 20,3 & 18,9 & 16,5 \\
\hline SC. & 7,2 & 7,0 & 7,2 & 6,5 & 7,1 & 7,1 & 7,8 & 7,6 & 7,9 & 7,8 & 8,0 & 8,0 & 7,1 & 7,2 & 6,6 & 7,5 & 6,8 & 6,6 & 7,3 & 8,7 \\
\hline SS. & 2,8 & 2,3 & 2,6 & 2,1 & 3,0 & 2,7 & 3,6 & 3,2 & 3,2 & 2,8 & 3,2 & 2,8 & 2,7 & 2,7 & 2,9 & 2,5 & 3,3 & 2,3 & 2,7 & 3,0 \\
\hline DC. & 21,3 & 20,1 & 20,9 & 19,3 & 20,4 & 19,7 & 21,4 & 20,2 & 21,5 & 20,3 & 21,9 & 20,4 & 21,0 & 19,6 & 21,6 & 20,2 & 19,4 & 18,2 & 22,0 & 20,6 \\
\hline DS. & 10,1 & 9,0 & 9,2 & 8,3 & 10,0 & 9,4 & 10,4 & 9,1 & 10,6 & 9,4 & 10,7 & 9,2 & 9,4 & 8,9 & 10,2 & 9,7 & 9,6 & 7,3 & 8,7 & 8,9 \\
\hline Сp. Числ. & 28 & 21 & 145 & 111 & 66 & 55 & 243 & 231 & 177 & 143 & 153 & 138 & 38 & 16 & 10 & 11 & 21 & 19 & 17 & 14 \\
\hline
\end{tabular}




\begin{tabular}{|c|c|c|c|c|c|c|c|c|c|c|c|c|c|c|c|c|c|c|}
\hline \multirow{4}{*}{$\begin{array}{l}\text { № по Мар- } \\
\text { тину, } \\
\text { или Услов- } \\
\text { ное обозна- } \\
\text { чение }\end{array}$} & \multicolumn{6}{|c|}{ Южносибирская антропологическая формация } & \multicolumn{6}{|c|}{ Североазиатская антропологическая формация } & \multirow{2}{*}{\multicolumn{6}{|c|}{$\begin{array}{c}\text { Беломоро-балтийская антропологическая формация } \\
\text { Приуральский антропологический тип }\end{array}$}} \\
\hline & \multirow{2}{*}{\multicolumn{2}{|c|}{$\begin{array}{l}\text { Алтае-саянский } \\
\text { антрополо- } \\
\text { гический тип }\end{array}$}} & \multirow{2}{*}{\multicolumn{2}{|c|}{$\begin{array}{c}\text { Северо- } \\
\text { алтайский } \\
\text { антрополо- } \\
\text { гический тип }\end{array}$}} & \multirow{2}{*}{\multicolumn{2}{|c|}{$\begin{array}{c}\text { Казахстанский } \\
\text { антропологический } \\
\text { тип }\end{array}$}} & \multirow{2}{*}{\multicolumn{2}{|c|}{$\begin{array}{l}\text { Центрально- } \\
\text { азиатский антропо- } \\
\text { логический тип }\end{array}$}} & \multirow{2}{*}{\multicolumn{2}{|c|}{$\begin{array}{c}\text { Байкальский } \\
\text { антропологиче- } \\
\text { ский тип }\end{array}$}} & \multirow{2}{*}{\multicolumn{2}{|c|}{ Монголы }} & & & & & & \\
\hline & & & & & & & & & & & & & \multicolumn{2}{|c|}{ Тюрки Приуралья } & \multicolumn{2}{|c|}{$\begin{array}{c}\text { Финны } \\
\text { Приуралья }\end{array}$} & \multicolumn{2}{|c|}{ Саамы } \\
\hline & 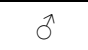 & q & $\hat{0}$ & 우 & $\hat{0}$ & 우 & o & 우 & $\hat{0}$ & 우 & 3 & 우 & o & 우 & $\hat{0}$ & 우 & $\hat{0}$ & q \\
\hline 1. & 178,9 & 172,2 & 179,2 & 171,7 & 178,2 & 172,7 & 183,2 & 173,8 & 181,5 & 173,8 & 182,7 & 172,6 & 180,1 & 174,8 & 179,3 & 171,6 & 179,0 & 172,4 \\
\hline 8. & 146,0 & 140,7 & 144,2 & 139,9 & 149,4 & 145,5 & 150,3 & 143,8 & 145,6 & 140,3 & 149,7 & 142,9 & 144,4 & 140,0 & 142,5 & 137,2 & 145,2 & 141,3 \\
\hline 17 & 132,9 & 127,3 & 134,3 & 128,1 & 130,8 & 127,6 & 133,6 & 127,5 & 127,8 & 123,5 & 131,2 & 125,7 & 132,4 & 126,4 & 133,8 & 129,0 & 130,6 & 124,9 \\
\hline $8: 1$. & 81,7 & 81,8 & 80,7 & 81,6 & 84,0 & 84,7 & 82,1 & 83,0 & 80,8 & 80,8 & 82,0 & 82,3 & 80,2 & 80,1 & 79,7 & 80,0 & 81,0 & 82,0 \\
\hline 5. & 100,6 & 95,5 & 100,4 & 95,7 & 101,4 & 97,2 & 102,9 & 96,9 & 100,7 & 95,5 & 101,5 & 94,5 & 101,2 & 95,6 & 101,0 & 95,9 & 100,6 & 95,3 \\
\hline 9. & 94,0 & 91,4 & 93,8 & 91,8 & 95,1 & 94,3 & 95,4 & 92,0 & 91,6 & 88,9 & 94,3 & 92,2 & 96,9 & 93,6 & 96,1 & 93,4 & 97,4 & 94,1 \\
\hline 32. & 82,1 & 84,7 & 83,2 & 86,1 & 81,7 & 83,4 & 80,4 & 83,9 & 79,4 & 82,5 & 80,5 & 83,0 & 82,0 & 85,8 & 84,7 & 87,1 & 81,9 & 82,8 \\
\hline 40. & 98,2 & 93,0 & 98,1 & 94,4 & 97,6 & 93,5 & 100,8 & 95,0 & 101,1 & 95,6 & 98,2 & 92,9 & 99,0 & 94,7 & 97,0 & 92,4 & 97,2 & 91,6 \\
\hline 45. & 139,9 & 130,4 & 136,4 & 127,5 & 142,1 & 133,4 & 143,7 & 132,3 & 140,4 & 130,7 & 142,2 & 131,3 & 135,4 & 126,3 & 133,2 & 123,7 & 135,2 & 126,6 \\
\hline 48. & 74,8 & 70,8 & 73,9 & 69,3 & 75,0 & 70,4 & 78,4 & 72,1 & 75,9 & 70,7 & 78,3 & 70,7 & 72,4 & 67,7 & 70,2 & 66,2 & 69,2 & 64,2 \\
\hline $48: 45$ & 52,9 & 54,3 & 54,4 & 54,4 & 52,9 & 52,9 & 54,5 & 54,3 & 5,1 & 54,0 & 55,1 & 53,8 & 53,5 & 53,3 & 52,7 & 53,5 & 51,2 & 50,8 \\
\hline 72. & 86,7 & 86,9 & 86,6 & 86,0 & 88,0 & 87,9 & 87,6 & 87,6 & 86,4 & 86,4 & 87,5 & 86,1 & 85,0 & 84,6 & 85,3 & 87,9 & 86,1 & 85,6 \\
\hline 77. & 145,2 & 145,4 & 144,0 & 144,2 & 144,8 & 143,7 & 146,3 & 147,5 & 149,1 & 149,0 & 146,4 & 145,6 & 140,4 & 141,1 & 141,0 & 141,3 & 141,0 & 141,8 \\
\hline$\angle \mathrm{zm} \prime$. & 134,3 & 133,9 & 131,7 & 132,8 & 133,5 & 135,3 & 140,2 & 140,0 & 139,4 & 140,9 & 138,4 & 138,2 & 130,4 & 129,6 & 128,8 & 128,1 & 130,9 & 130,6 \\
\hline 51. & 43,0 & 41,5 & 42,6 & 41,0 & 43,2 & 41,6 & 43,0 & 40,9 & 42,7 & 40,3 & 43,0 & 41,0 & 42,3 & 41,3 & 41,3 & 39,8 & 42,3 & 40,2 \\
\hline 52. & 34,5 & 34,4 & 34,0 & 33,4 & 35,2 & 34,4 & 35,4 & 34,4 & 34,8 & 34,0 & 36,0 & 34,9 & 33,3 & 32,1 & 32,8 & 32,2 & 33,1 & 32,2 \\
\hline 55. & 53,9 & 51,3 & 53,5 & 49,7 & 54,8 & 51,9 & 56,2 & 52,5 & 55,4 & 51,5 & 56,4 & 52,0 & 52,5 & 49,2 & 51,1 & 48,0 & 51,5 & 47,6 \\
\hline 54. & 25,6 & 24,8 & 25,6 & 25,0 & 26,5 & 25,5 & 26,9 & 26,1 & 26,8 & 25,5 & 27,4 & 25,8 & 25,2 & 24,2 & 24,7 & 24,2 & 25,0 & 24,2 \\
\hline $75(1)$. & 22,9 & 20,0 & 22,5 & 19,0 & 23,8 & 20,7 & 20,4 & 17,7 & 17,6 & 14,8 & 22,4 & 16,2 & 26,0 & 23,0 & 26,3 & 23,1 & 27,4 & 22,8 \\
\hline SC. & 7,6 & 7,4 & 7,8 & 7,8 & 8,4 & 8,8 & 8,1 & 7,7 & 6,9 & 7,0 & 7,1 & 7,9 & 8,8 & 8,4 & 8,8 & 8,6 & 8,4 & 8,3 \\
\hline SS. & 3,5 & 2,9 & 3,4 & 2,9 & 3,8 & 3,3 & 2,9 & 2,3 & 2,4 & 1,8 & 2,8 & 2,8 & 4,0 & 3,7 & 4,0 & 3,5 & 4,4 & 3,6 \\
\hline DC. & 20,4 & 19,5 & 20,7 & 20,3 & 21,5 & 21,5 & 22,0 & 20,7 & 20,4 & 20,2 & 20,6 & 20,7 & 21,6 & 21,0 & 21,4 & 20,7 & 21,5 & 21,0 \\
\hline DS. & 10,2 & 9,3 & 9,9 & 8,9 & 10,5 & 9,9 & 9,2 & 7,9 & 8,0 & 7,2 & 9,3 & 8,7 & 11,6 & 10,7 & 11,9 & 10,6 & 11,8 & 10,3 \\
\hline Сp. Числ. & 237 & 255 & 217 & 189 & 181 & 155 & 217 & 156 & 75 & 54 & 184 & 118 & 462 & 333 & 284 & 255 & 71 & 52 \\
\hline
\end{tabular}



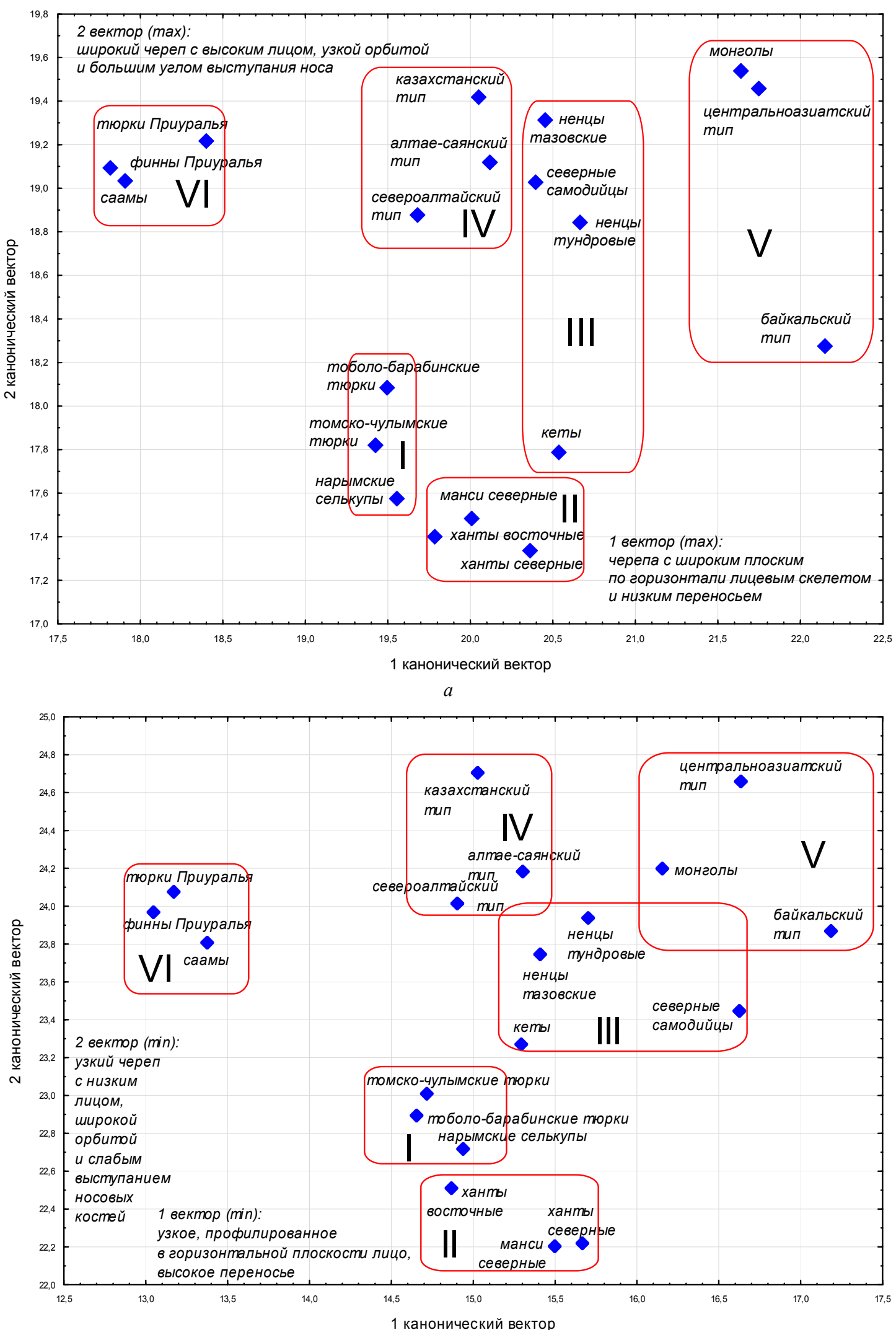

$\sigma$

Рис. 1. Расположение мужских (a) и женских (б) североевразийских групп в корреляционном поле 1-го и 2-го канонических векторов: I - обь-иртышский антропологический тип западносибирской антропологической формации; II - уральский антропологический тип западносибирской антропологической формации; III - ямало-енисейский антропологический тип западносибирской антропологической формации; IV - южносибирская антропологическая формация; $V$ - североазиатская антропологическая формация;

VI - приуральский антропологический тип беломоро-балтийской антропологической формации 


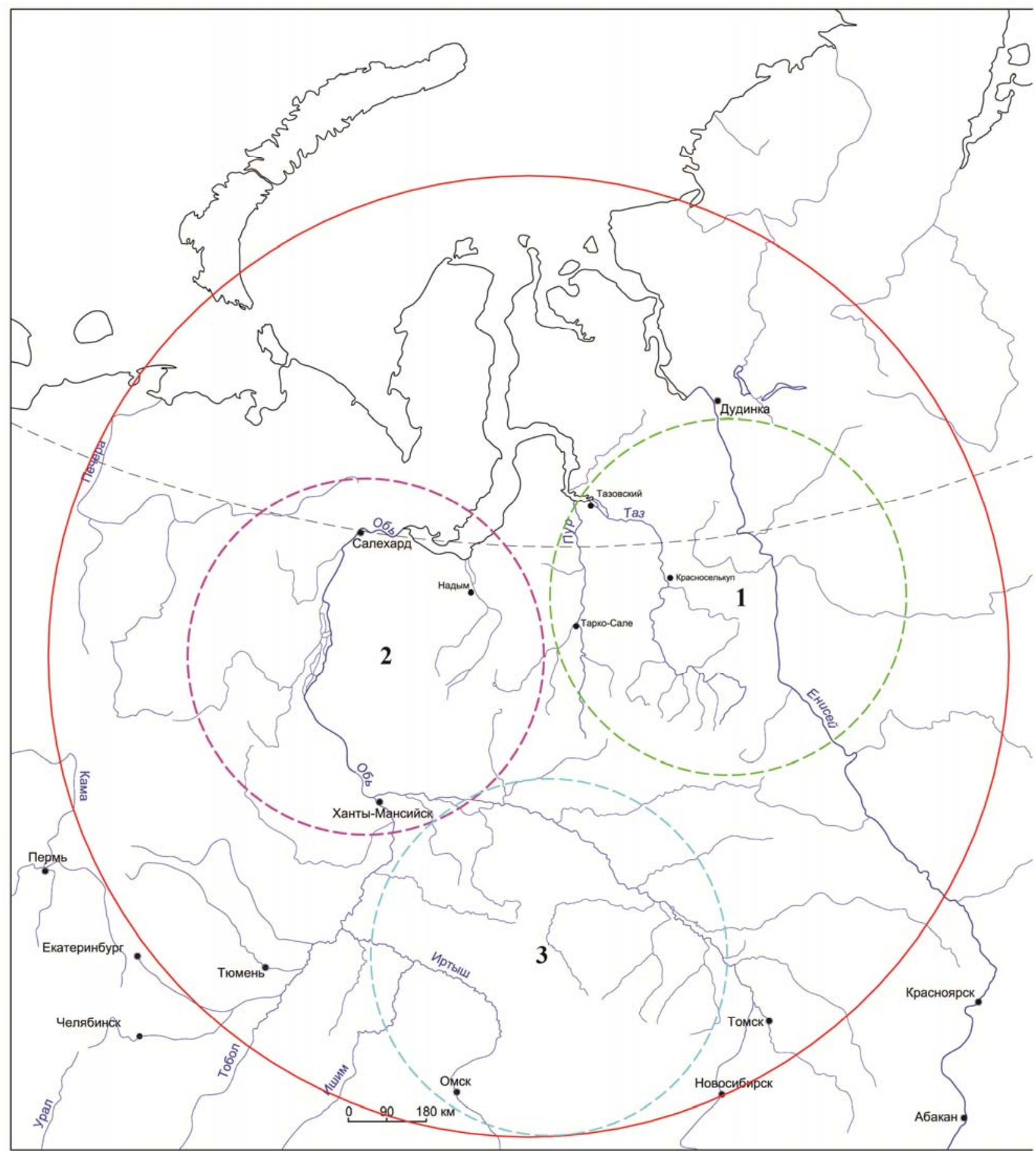

- западносибирский вторичный очаг расообразования

- 1 - ямало-енисейский третичный очаг расообразования

- 2 - уральский третичный очаг расообразования

- 3 - обь-иртышский третичный очаг расообразования

Рис. 2. Западносибирский вторичный очаг расообразования с дочерними третичными:

1 - ямало-енисейский третичный очаг расообразования;

2 - уральский третичный очаг расообразования;

3 - обь-иртышский третичный очаг расообразования 
Величины нагрузок по 1-му и 2-му каноническим векторам

\begin{tabular}{|c|c|c|c|c|}
\hline \multirow{2}{*}{ № по Мартину, или Условное обозначение } & \multicolumn{2}{|c|}{ 1-й канонический вектор } & \multicolumn{2}{|c|}{ 2-й канонический вектор } \\
\hline & $\hat{0}$ & q & $\hat{0}$ & 오 \\
\hline 1. Продольный диаметр & 0,1172 & $-0,0040$ & 0,0206 & 0,0184 \\
\hline 8. Поперечный диаметр & 0,2371 & 0,1590 & 0,4805 & 0,5692 \\
\hline 17. Высотный диаметр $(b a-b)$ & $-0,1600$ & $-0,1193$ & 0,2066 & 0,1799 \\
\hline 45. Скуловой диаметр & 0,3449 & $\mathbf{0 , 3 8 4 1}$ & $-0,1161$ & $-0,1096$ \\
\hline 48. Верхняя высота лица & 0,3167 & 0,2096 & 0,5556 & $\mathbf{0 , 5 7 8 6}$ \\
\hline 77. Назомалярный угол & 0,3694 & 0,3449 & $-0,0084$ & 0,1032 \\
\hline$\angle \mathrm{zm}$ '. Зигомаксиллярный угол & 0,3876 & $\mathbf{0 , 4 3 7 1}$ & $-0,0177$ & 0,0753 \\
\hline 51. Ширина орбиты от $m f$. & $-0,0357$ & $-0,0688$ & $-0,3542$ & $-0,3314$ \\
\hline 52. Высота орбиты & 0,1503 & 0,2517 & $-0,0200$ & $-0,1102$ \\
\hline 75(1). Угол выступания носа & $-0,2020$ & $-0,2626$ & 0,4650 & 0,3249 \\
\hline SS. Симотическая высота & $-0,2898$ & $-0,2957$ & 0,1670 & 0,0963 \\
\hline DC. Дакриальная ширина & $-0,1809$ & $-0,2006$ & $-0,0376$ & 0,1293 \\
\hline DS. Дакриальная высота & $-0,4660$ & $-0,4407$ & 0,1788 & 0,1632 \\
\hline Собственные значения & 262,95 & 174,61 & 91,76 & 70,21 \\
\hline \% описываемой изменчивости & 56,7 & 52,9 & 19,8 & 21,3 \\
\hline
\end{tabular}

Выделены максимальные нагрузки.

Для выяснения общих закономерностей межгрупповой изменчивости североевразийских народов их морфологические особенности проанализированы с помощью многомерной статистики - канонического анализа (использовалась программа Ю.К. Чистова). Для стабилизации изменчивости краниологические данные по надпопуляционным общностям суммированы невзвешенно, чтобы отразить вклад каждой выборки в обобщенный морфологический тип. Таким образом обобщены мужские и женские серии по байкальскому $[12,13]$, центральноазиатскому [Там же], алтаесаянскому $[13,14]$, североалтайскому [12-14], казахстанскому [13], обь-иртышскому (тоболо-барабинские тюрки $[15,16])$, томско-нарымскому (томскочулымские тюрки $[17,18]$ и нарымские селькупы $[19-$ 21]), уральскому (северные манси [12], северные [12, 22] и восточные [23] ханты)) и приуральскому (тюрки $[24,25]$ и финны [26] Приуралья, саамы [27]) антропологическим типам. Материал по северным самодийцам сгруппирован следующим образом: ненцы тундровые [12], ненцы тазовские [10] и сборная серия по северным самодийцам (нганасаны [28], ненцы надымские [11], ненцы Яр-Сале и р. Щучья [22]). Кетская серия используется по данным И.И. Гохмана и В.А. Дремова [22, 29]. Краниологические характеристики образованных мужских и женских обобщенных групп представлены в табл. 1.

Первые два вектора описывают 76,5\% общей дисперсии мужских выборок и 74,2\% женских, причем особенности изменчивости по мужским и женским материалам практически полностью совпадают. И в той и в другой совокупностях наибольшие нагрузки по 1-му каноническому вектору приходятся на серии, где преобладают черепа с широким и уплощенным по горизонтали на обоих уровнях лицевым скелетом с низким переносьем, а минимальные, соответственно, наоборот (табл. 2). Данным комплексом признаков выборки дифференцируются по степени выраженности монголоидных/европеоидных черт, максимально дистанцируются в данном случае североазиатские монголоиды и европеоиды Приуралья, западносибирские, северосамодийские и южносибирские выборки занимают между этими крайними вариантами промежуточное положение (рис. 1).

Комплекс признаков 2-го канонического вектора дифференцирует группы по ширине черепа, высоте лицевого скелета, ширине орбиты и углу выступания носа. Максимальные нагрузки приходятся на брахикранные черепа с высоким лицевым скелетом и сильно выступающим носом, минимальные - на черепа долихокранные с лептоморфным строением лица и слабым выступанием носовых костей. Эти признаки также таксономически важны при дифференциации европеоидов и монголоидов, но именно они отделяют южносибирскую совокупность от западносибирской (см. рис. 1).

Обобщенно видно, что гармоничное сочетание признаков характерно для классических монголоидов и европеоидов. Относительно дисгармоничное сочетание признаков наблюдается в южносибирской совокупности, когда монголоидные особенности строения черепной коробки и лица сочетаются с европеоидным строением горизонтального профиля лицевого скелета в сочетании с выступающим переносьем и носовыми костями. Для западносибирских групп свойственно еще более дисгармоничное сочетание монголоидного комплекса (слабое выступание носовых костей, плоского по горизонтали лица и переносья) с европеоидными чертами строения мозговой коробки (долихокранный череп с узким и низким лицом). Но именно данное сочетание особенностей определяет антропологическую специфику западносибирских популяций, особенно уральского типа, что служит индикатором былого расогенетического единства. Этот же комплекс характерен (но в ослабленном виде и с тяготением в сторону южносибирских популяций, особенно по мужским черепам) для северосамодийских групп. Данное наблюдение еще раз может выступать свидетельством древ- 
него алтае-саянского происхождения северных самодийцев. Интересно, что по женским материалам эта тенденция едва просматривается. Для краниологического типа кетов свойственно в целом сочетание признаков, характерное для западносибирских групп, но с рядом особенностей, которые сближают их все-таки с северосамодийскими выборками (см. рис. 1).

Антропологическую специфику северных самодийцев, с учетом отмеченных тенденций, как и всех западносибирских популяций, особенно уральского типа, определяет один и тот же фактор, что служит индикатором былого генетического единства. Однако особенности их межгрупповой изменчивости, особенно по мужским материалам, позволяют видеть в данной совокупности популяций два краниологических варианта. Один характерен для северных самодийцев, поэтому его логично обозначить как ямальский, другой свойствен кетам, его предлагается обозначить как енисей- ский. Обе категории могут быть объединены в один таксон, который предлагается рассматривать в качестве третьего антропологического типа в составе западносибирской антропологической формации под названием ямало-енисейского. Соответственно в составе западносибирского вторичного очага расообразования может быть выделен дополнительный третичный очаг - ямало-енисейский, наряду с обь-иртышским и уральским (рис. 2).

Судя по характеру рассеивания южносибирские популяции, действительно, сформировались в результате длительного взаимодействия монголоидных и европеоидных форм, тогда как в генезисе западносибирских народов, включая северных самодийцев и кетов, заметную роль сыграла консервация недифференцированных элементов, а метисационные процессы оказали свое влияние только на финальных этапах их формирования.

\section{ЛИТЕРАТУРА}

1. Деникер И.Е. Человеческие расы. СПб., 1902. 724 с.

2. Гинзбург В.В., Трофимова Т.А. Палеоантропология Средней Азии. М. : Наука, 1972. 372 с.

3. Гохман И.И. Роль андроновского компонента в формировании южносибирской расы // Советская этнография. 1973. № 2. С. 96-106.

4. Исмагулов О. Население Казахстана от эпохи бронзы до современности. Алма-Ата, 1970. 240 с.

5. Дебец Г.Ф. О принципах классификации человеческих рас // Советская этнография. 1956. № 4. С. 129-142.

6. Алексеев В.П. О смешанном происхождении уральской расы // Вопросы археологии Урала. Свердловск, 1961. Вып. 1. С. 117-120.

7. Бунак В.В. Человеческие расы и пути их образования // Советская этнография. 1956. № 1. С. 86-105.

8. Бунак В.В. Род Ното, его возникновение и последующая эволюция. М. : Наука, 1980. 328 с.

9. Багашев А.Н. Антропологические общности, их систематика и особенности расообразовательных процессов // Очерки культурогенеза коренного населения Западной Сибири. Томск : Изд-во Том. ун-та, 1998. Т. 4 : Расогенез коренного населения. С. 303-327.

10. Багашев А.Н., Слепченко С.М. Материалы по краниологии тазовских ненцев // Человек и Север: Антропология, археология, экология. Тюмень, 2015. Вып. 3. С. 6-10.

11. Багашев А.Н., Ражев Д.И. Надымский городок. Палеоантропологическое исследование // Вестник археологии, антропологии и этнографии. 2009. № 11. С. 111-124.

12. Дебец Г.Ф. Антропологические исследования в Камчатской области // Труды Института этнографии. 1951. Т. 17. 264 с.

13. Алексеев В.П., Гохман И.И. Антропология азиатской части СССР. М. : Наука, 1984. 208 с.

14. Дремов В.А., Ким А.Р. Население северных предгорий Алтая // Очерки культурогенеза коренного населения Западной Сибири. Томск : Изд-во Том. ун-та, 1998. Т. 4: Расогенез коренного населения.

15. Ким А.Р. Барабинские татары // Очерки культурогенеза коренного населения Западной Сибири. Томск: Изд-во Том. ун-та, 1998. Т. 4 : Расогенез коренного населения. С. 84-94.

16. Багашев А.Н. Этническая антропология тоболо-иртышских татар. Новосибирск : Наука, 1993. 152 с.

17. Дремов В.А. Томские и чулымские тюрки // Очерки культурогенеза коренного населения Западной Сибири. Томск: Изд-во Том. ун-та, 1998. Т. 4: Расогенез коренного населения. С. 67-84.

18. Багашев А.Н. Антропологический тип средневековых тюрков Нижнего Притомья (могильник Астраханцево) // Проблемы взаимодействия человека и природной среды. Тюмень, 2003. Вып. 4. С. 68-73.

19. Дремов В.А. Нарымские селькупы // Очерки культурогенеза коренного населения Западной Сибири. Томск : Изд-во Том. ун-та, 1998. Т. 4 : Расогенез коренного населения. С. 110-111.

20. Багашев А.Н. Хронологическая изменчивость краниологического типа нарымских селькупов // Вестник археологии, антропологии и этнографии. 2000. Вып. 3. С. 159-174.

21. Багашев А.Н. Антропологический состав населения Прикетья (Лукьяновский и Максимоярский могильники) // Проблемы взаимодействия человека и природной среды. Тюмень, 2002. Вып. 3. С. 40-43.

22. Дремов В.А. Расовая дифференциация угорских и самодийских групп Западной Сибири по данным краниологии // Проблемы антропологии древнего и современного населения севера Евразии. Л. : Наука, 1984. С. 106-132.

23. Дремов В.А. Краниология среднеобских хантов // Обские угры: Ханты и манси. М. : Ин-т этнологии и антропологии РАН, 1991. С. 10-28.

24. Юсупов Р.М. Краниология башкир. Л. : Наука, 1989. 200 с.

25. Алексеев В.П. Очерк происхождения тюркоязычных народов Восточной Европы в свете данных антропологии // Вопросы этногенеза тюркоязычных народов Среднего Поволжья. Казань : Татар. кн. изд-во, 1971. С. 232-271.

26. Алексеев В.П. Происхождение народов Восточной Европы. М. : Наука, 1969. 324 с.

27. Хартанович В.И. Новые материалы к краниологии саамов Кольского полуострова // Сборник Музея антропологии и этнографии. 1980. T. 36. C. 35-47.

28. Алексеев В.П. К краниологии нганасанов // Краткие сообщения Института этнографии. 1955. Вып. 24. С. 7-65.

29. Гохман И.И. Антропологические аспекты кетской проблемы: Результаты антропометрических и краниологических исследований // Кетский сборник. Л. : Наука, 1982. С. 9-42.

Bagashev Anatoly N. Institute of Problems of Development of the North Siberian Branch the Russian Academy of Sciences (Tyumen, Russia). E-mail: bagashev@mail.ru

INTERGROUP VARIABILITY OF CRANIAL SPECIAL FEATURES OF THE NORTHERN SAMOYEDS AND KETS.

Keywords: Anthropology; population; systematics; taxonomy; Northern Eurasia; Northern Samoyeds; Kets. 
Indigenous population of Northern Eurasia consists of various ethno-linguistic entities (Samoyeds, Finno-Ugric, Turkic, Kets, PaleoAsiatics). Historical anthropology, studying stages of formation of special characteristics of their physical appearance, attaches great significance to classification of anthropological communities, as it reflects common elements and differences in the genesis and historical background of populations. Therefore, systematics of anthropological communities receives much attention. As to the territory of Northern Eurasia, the most famous taxonomy was made by I. Deniker, which was later supplemented and specified. He separated northern populations of the region into the Ugric community, later V.V. Bunak allocated them into the Ural anthropological community. However, accumulation of new significant data on the anthropology of the population of the Ural community in the XX century has significantly increased the level of its inter-group variability. It was suggested to specify a number of variants within this community in order to remedy situation (Subural, Lapponoid, Sublapponoid, West Siberian, Ural, Northern Altai). However, the overall variability has not diminished, but increased. In this regard, the author suggested to abandon the notion of the Ural community as a combination Subural, Northern Altai, West Siberian populations and Kets. Variability of new taxa decreased to a comparable level, but taxonomic positions of the Northern Samoyeds and Kets remained uncertain due to the lack of data about their variability. New materials on these groups specified the location of the Northern Samoyeds and Kets in the system of superpopulational communities of Northern Eurasia. One and the same factor determines their anthropological specificity, as well as the specificity of all Western Siberian populations, especially of the Ural type, which serves as an indicator of preceding genetic unity. Therefore, Northern Samoyeds and Kets are suggested to be considered as the third anthropological type within the West Siberian anthropological formation and to be called Yamal-Yenisei along with the Ob-Irtysh and Ural types. Respectively, it is necessary to allocate an additional tertiary center (Yamalo-Yenisei) within the West Siberian secondary center of morphogenesis.

\section{REFERENCES}

1. Deniker, I.E. (1902) Chelovecheskie rasy [Human race]. St. Petersburg: Bol'shakov i Golova.

2. Ginzburg, V.V. \& Trofimova, T.A. (1972) Paleoantropologiya Sredney Azii [Paleoanthropology in Central Asia]. Moscow: Nauka.

3. Gokhman, I.I. (1973) Rol' andronovskogo komponenta v formirovanii yuzhnosibirskoy rasy [The role of the Andronovo component in the formation of the South Siberian race]. Sovetskaya etnografiya. 2. pp. 96-106.

4. Ismagulov, O. (1970) Naselenie Kazakhstana ot epokhi bronzy do sovremennosti [The population of Kazakhstan from the Bronze Age to the present]. Alma-Ata: Nauka.

5. Debets, G.F. (1956) O printsipakh klassifikatsii chelovecheskikh ras [On the principles of human race classification]. Sovetskaya etnografiya. 4. pp. 129-142.

6. Alekseev, V.P. (1961) O smeshannom proiskhozhdenii ural'skoy rasy [On the mixed origins of the Ural race]. In: Gening, V.F. (ed.) Voprosy arkheologii Urala [The Archeology of the Urals]. Issue 1. Sverdlovsk: Urals State University. pp. 117-120.

7. Bunak, V.V. (1956) Chelovecheskie rasy i puti ikh obrazovaniya [Human races and the ways of their formation]. Sovetskaya etnografiya. 1. pp. 86-105.

8. Bunak, V.V. (1980) Rod Homo, ego vozniknovenie i posleduyushchaya evolyutsiya [Homo, its origin and evolution]. Moscow: Nauka.

9. Bagashev, A.N. (1998) Antropologicheskie obshchnosti, ikh sistematika i osobennosti rasoobrazovatel'nykh protsessov [The anthropological communities, their taxonomy and race-formation processes]. In: Bagashev, A.N. (ed.) Ocherki kul'turogeneza korennogo naseleniya Zapadnoy Sibiri [Essays on the cultural genesis of the indigenous peoples of Western Siberia]. Vol. 4. Tomsk: Tomsk State University. pp. $303-327$.

10. Bagashev, A.N. \& Slepchenko, S.M. (2015) [Craniology of the Taz Nenets]. Chelovek i Sever: Antropologiya, arkheologiya, ekologiya [Man and the North: Anthropology, Archeology, Ecology]. Proc. of the Third All-Russian Conference. Tyumen, 6-10 April 2015. Tyumen. pp. 6-10. (In Russian).

11. Bagashev, A.N. \& Razhev, D.I. (2009) The Nadym fortified settlement. A paleoanthropological investigation. Vestnik arkheologii, antropologii $i$ etnografii - Bulletin of Archaeology, Anthropology and Ethnography. 11. pp. 111-124. (In Russian).

12. Debets, G.F. (1951) Antropologicheskie issledovaniya v Kamchatskoy oblasti [The anthropological studies in Kamchatka Region]. Trudy Instituta etnografii. 17.

13. Alekseev, V.P. \& Gokhman, I.I. (1984) Antropologiya aziatskoy chasti SSSR [Anthropology of the Asian part of the USSR]. Moscow: Nauka.

14. Dremov, V.A. \& Kim, A.R. (1998) Naselenie severnykh predgoriy Altaya [The population of the northern foothills of Altai]. In: Bagashev, A.N. (ed.) Ocherki kul'turogeneza korennogo naseleniya Zapadnoy Sibiri [Essays on the cultural genesis of the indigenous peoples of Western Siberia]. Vol. 4. Tomsk: Tomsk State University.

15. Kim, A.R. (1998) Barabinskie tatary [The Baraba Tatars]. In: Bagashev, A.N. (ed.) Ocherki kul'turogeneza korennogo naseleniya Zapadnoy Sibiri [Essays on the cultural genesis of the indigenous peoples of Western Siberia]. Vol. 4. Tomsk: Tomsk State University. pp. 84-94.

16. Bagashev, A.N. (1993) Etnicheskaya antropologiya tobolo-irtyshskikh tatar [The ethnic anthropology of Tobol-Irtysh Tatars]. Novosibirsk: Nauka.

17. Dremov, V.A. (1998a) Tomskie i chulymskie tyurki [Tomsk and Chulym Turks]. In: Bagashev, A.N. (ed.) Ocherki kul'turogeneza korennogo naseleniya Zapadnoy Sibiri [Essays on the cultural genesis of the indigenous peoples of Western Siberia]. Vol. 4. Tomsk: Tomsk State University. pp. 67-84.

18. Bagashev, A.N. (2003) [The anthropological type of medieval Turks of the Lower Tom (the Astrakhantsevo Burial)]. Problemy vzaimodeystviya cheloveka i prirodnoy sredy [Problems of interaction between Man and nature]. Proc. of the Final Scientific Session of the Institute of the Problems of North Development. Issue 4. Tyumen. pp. 68-73.

19. Dremov, V.A. (1998b) Narymskie sel'kupy [The Narym Selkups]. In: Bagashev, A.N. (ed.) Ocherki kul'turogeneza korennogo naseleniya Zapadnoy Sibiri [Essays on the cultural genesis of the indigenous peoples of Western Siberia]. Vol. 4. Tomsk: Tomsk State University. pp. $110-111$.

20. Bagashev, A.N. (2000) Khronologicheskaya izmenchivost' kraniologicheskogo tipa narymskikh sel'kupov [The chronological variability of the craniological type of the Narym Selkups]. Vestnik arkheologii, antropologii i etnografii-Bulletin of Archaeology, Anthropology and Ethnography. 3. pp. 159-174.

21. Bagashev, A.N. (2002) Antropologicheskiy sostav naseleniya Priket'ya (Luk'yanovskiy i Maksimoyarskiy mogil'niki) [The anthropological composition of the Priketye population (Lukyanovo and Maksimoyarsk Burials)]. Problemy vzaimodeystviya cheloveka i prirodnoy sredy [Problems of interaction between Man and nature]. Proc. of the Scientific Session of the Institute of the Problems of North Development. Issue 3. Tyumen. pp. 40-43.

22. Dremov, V.A. (1984) Rasovaya differentsiatsiya ugorskikh i samodiyskikh grupp Zapadnoy Sibiri po dannym kraniologii [The racial differentiation of Ugric and Samoyed groups of Western Siberia by craniology]. In: Gokhman, I.I. (ed.) Problemy antropologii drevnego i sovremennogo naseleniya severa Evrazii [Problems of anthropology of ancient and modern population of Northern Eurasia]. Leningrad: Nauka. pp. 106-132.

23. Dremov, V.A. (1991) Kraniologiya sredneobskikh khantov [Craniology of the Middle Ob Khanty]. In: In: Sokolova, Z.P. (ed.) Obskie ugry: Khanty $i$ mansi [The Ob Ugric peoples: Khanty and Mansi]. Moscow: Institute of Ethnology and Anthropology of the Russian Academy of Sciences. pp. 10-28.

24. Yusupov, R.M. (1989) Kraniologiya Bashkir [Craniology of the Bashkirs]. Leningrad: Nauka.

25. Alekseev, V.P. (1971) Ocherk proiskhozhdeniya tyurkoyazychnykh narodov Vostochnoy Evropy v svete dannykh antropologii [An essay on the origin of the Turkic-speaking peoples of Eastern Europe in terms of anthropology]. In: Khalikov, A.Kh. (ed.) Voprosy etnogeneza tyurkoyazychnykh narodov Srednego Povolzh'ya [Problems of ethnogenesis of Turkic-speaking peoples of the Middle Volga]. Kazan: Tatar Book Publ. pp. 232-271.

26. Alekseev, V.P. (1969) Proiskhozhdenie narodov Vostochnoy Evropy [The origin of the Eastern European peoples]. Moscow: Nauka.

27. Khartanovich, V.I. (1980) Novye materialy k kraniologii saamov Kol'skogo poluostrova [New materials to the craniology of the Saami in the Kola Peninsula]. In: Reshetov, A.M. (ed.) Sbornik Muzeya antropologii $i$ etnografii [The Collection of the Museum of Anthropology and Ethnography]. Vol. 36. pp. 35-47.

28. Alekseev, V.P. (1955) K kraniologii nganasanov [On the craniology of the Nganasan]. Kratkie soobshchenie Instituta etnografii. 24 . pp. 7-65.

29. Gokhman, I.I. (1982) Antropologicheskie aspekty ketskoy problemy: Rezul'taty antropometricheskikh i kraniologicheskikh issledovaniy [Anthropological aspects of the Kets problems: The results of anthropometric and cranial studies]. In: Uspenskiy, B.A. (ed.) Ketskiy sbornik [The Kets collection]. Leningrad: Nauka. pp. 9-42. 